\title{
The Origins of Central Banking: Solutions to the Free-Rider Problem
}

\author{
J. Lawrence Broz
}

Certain domestic institutions are sources of international power, by way of their abilities to encourage investment and to mobilize social resources in wartime. For example, states with democratic institutions almost always win the wars they fight, a regularity known as the "democratic advantage." ${ }^{1}$ This result is intriguing since it rests on intuition about the effects of military competition on domestic institutions: rivalry among states may put pressure on sovereigns to provide the political foundations for secure markets in order to enlarge future military capabilities.

In this article I address the role of war in inducing domestic institutions that allowed governments to credibly commit to promises to pay their debts-a probable source of democracies' edge in war. Rather than investigate the entire range of protections affected by democratic institutions - a life's endeavor, as the work of Douglass North attests-I focus on a single financial element of the reforms: the innovation of central banking. Britain's superior financial, economic, and military performance after 1689 rested in large part on the establishment of the Bank of England. ${ }^{2}$ The central bank provided a commitment technology that improved the government's ability to borrow, a need impelled by intense military competition. ${ }^{3}$

My motivation derives from puzzles concerning the origins and the diffusion of credibility-enhancing institutions like central banks. Institutions resolve collective action problems, but institutions themselves are public goods, meaning that their origins are subject to the same dilemmas they are meant to resolve. ${ }^{4}$ What then explains the incentives of self-interested and free-riding individuals to contribute to

This is a revised version of a paper delivered at the 1996 Annual Meeting of the American Political Science Association. I thank Marc Busch, William R. Clark, Jeffrey Frieden, Kevin Grier, Mark Hallerberg, Robert Keohane, David Lane, Lisa Martin, George Selgin, Beth Simmons, Daniel Verdier, and three anonymou s reviewers for helpful comments. Melissa Freeman provided valuable editorial assistance.

1. See Schultz and Weingast 1996; and Lake 1992.

2. See North and Weingast 1989; Weingast 1992; and Root 1994.

3. For a related analysis, see Grief, Milgrom, and Weingast 1994.

4. Knight 1992. 
institutions that bind governments? Furthermore, if domestic political institutions are shaped by the relentless competition of the anarchic international system, why do institutional innovations that prove advantageous not diffuse readily to all states?

\section{The Collective Action Conundrum}

Consider the now classic article on the Glorious Revolution by Douglass North and Barry Weingast. ${ }^{5}$ Sovereigns, they argue, needed loans to finance wars but were constrained by citizens' fears that monarchs would exploit their abilities to default with impunity after the war. In other words, monarchs faced a problem of time inconsistency and credibility vis-à-vis domestic actors: because they could not credibly commit to their promises to respect property and to pay debts, sovereigns suffered, not least in their ability to mobilize credit in wartime. The solution was to delegate power over government credit decisions to Parliament and a central bank. By relinquishing authority over lending decisions to Parliament, the Crown gave representatives of wealthholders veto power over decisions about honoring loan agreements, lowering the probability of default. The Bank of England, however, was crucial. "In view of its services to the stability of public finance and the improvement of public borrowing from the year of its foundation, it is hard to resist the conclusion that no institution contributed more to the stability of the Revolution settlement or underwrote more effectively the liberties that Englishmen enjoyed during the eighteenth century." 6

The Bank of England contained an explicit commitment technology that secured creditors' property rights. ${ }^{7}$ The key innovation was the proviso in its charter granting the Bank a dominant position in managing government finances. By centralizing all lending to the government within the Bank, the government created a "private constraint on its future behavior by making it difficult to utilize funds of a current loan if it failed to honor its previous obligations." 8

This innovation produced several important forward benefits that permitted the drive toward British hegemony and dominance of the world. It improved government creditworthiness. J. R. Jones notes that by "institutionalizing those who provided long-term finance in the Bank of England, Parliament effectively tied the hands of later Parliaments and administrations," thereby greatly improving the government's access to credit. ${ }^{9}$ Improved creditworthiness in turn had considerable fiscal and economic benefits that helped propel England to international power. Most importantly, it allowed the government to reduce the distortions associated with financing abnormally high wartime expenditures with high current taxation (or the inflation

5. North and Weingast 1989; see also Root 1994.

6. Dickson and Sperling 1970, 289; see also North and Weingast 1989; Weingast 1992; and Root 1994.

7. See Macaulay 1831; and Hicks 1969, 93-95.

8. North and Weingast $1989,821$.

9. Jones $1994,82$. 
tax) by following a more efficient "tax smoothing" policy. ${ }^{10}$ Financing wartime expenditures by borrowing, then servicing and amortizing the debt by taxation in peacetime, lowers the total costs of raising revenue because it produces fewer distortions in the investment decisions of private economic agents. In short, with the Bank of England in place to constrain government opportunism, Britain suffered less from the resource drain of war than did its rivals. ${ }^{11}$

The microfoundations of this analysis are solid, up to a point. There are two parties to such exchanges - the sovereign and the citizens - and both have incentives to create a central bank. For the sovereign, giving away discretion on lending decisions is rational, since this actually strengthens state power: the institutional restrictions are self-enforcing for the sovereign. For the citizenry, in turn, obtaining discretion from the Crown means citizens secure greater protection of private property rights. Hence, both parties benefit from the institutional bargain.

The account, however, downplays and even ignores a basic incentive problem. Unlike the sovereign, which is a unitary actor, citizens undeniably face a collective action dilemma. To put it generally, institutions that reinforce government commitments are public goods for citizens; the benefits accrue undiminished to all members, whether or not individuals contribute to their provision. Given this, the supply of institutions that protect citizens from predatory government behavior faces the freerider problem. The problem is quite general: "Even if payoffs were symmetric [as in an assurance game] and all people were made (equally) better off from the introduction of the institution, there would still be a failure of supply, since the institution would provide a collective good and rational individuals would seek to secure its benefits for free. The incentives to free ride would undermine the incentives to organize a solution to the collective dilemma. It is subject to the very incentive problems it is supposed to resolve." 12

Inasmuch as the Bank of England produced nonexcludable benefits to be enjoyed by nearly all citizens, organization and participation in the venture should have been difficult-as much so, in theory, as the prior problem of coordinating lending decisions to the government before the innovation. The diffuse benefits of central banking would be insufficient to mobilize social actors to participate in the venture, precisely because the outputs were public goods. Since the advantages of strengthened government credit and more efficient fiscal policy accrue to all taxpaying members of society, whether they share in the costs of constructing a central bank or not, each citizen would calculate that free riding was the optimal strategy. To contribute, so as to avoid the distortions of excessively high current taxation, would be irrational since the gains could not be restricted to only those who participated. With all potential beneficiaries thinking the same way, the project would fail, and the public goods would remain underprovided. What then made the Bank of England, and early central banking more generally, so successful?

10. Barro 1987.

11. Sargent and Velde 1995 .

12. Bates 1988, 394-95; see also Knight 1992. 
One approach is to treat the citizenry's collective action problem as insurmountable and thereby posit that the origin of institutions always comes at the initiative of the state: "institutional innovation will come from rulers rather than constituents since the latter would always face the free rider problem." 13 Yet building political institutions is inherently an exercise in voluntary exchange, requiring participation by at least two parties, the state and its citizens. To summarily dismiss analysis of one party's incentives and behavior violates basic axioms of political economy. ${ }^{14}$

Collective action theory, however, provides at least two relevant models for thinking about how large groups surmount such problems. The first is the "privileged group" model, which relaxes the condition of uniform, symmetrical benefits. ${ }^{15}$ If the gains from collective action are distributed unevenly within a community, then the benefit going to one or to several members may be sufficient to justify this subgroup providing the public good single-handedly, even if other beneficiaries free ride. A privileged-group story may in fact be what North and Weingast have in mind, since their focus is on a concentrated subset of society, namely, private wealthholders. ${ }^{16}$ Hilton Root is most explicit, arguing that Parliament represented the interests of creditors, and that the increase in the power of Parliament was the source of England's subsequent financial-military successes. ${ }^{17}$ It is doubtful, however, that the institutions of the Glorious Revolution arose because creditors, expecting to gain disproportionately, mobilized to supply them. Parliament in fact did not represent the mercantile and financial interests who loaned money to the government. Rather, the traditional landed elite dominated both Houses of Parliament until well into the nineteenth century. ${ }^{18}$ Furthermore, it is unlikely that the landed gentry represented and protected the interests of the creditors, given the public policy conflicts that dominated relations between the two groups. ${ }^{19}$

A second approach to collective action in large group settings is the "joint products" or "selective incentives" model. The basic intuition of the model is that collective action situations typically yield multiple benefits, public and private. ${ }^{20}$ For example, charitable organizations produce a public good (philanthropic activities) as well as private, agent-specific benefits (tax breaks for contributors).$^{21}$ The basic point is that the presence of joint products means that the relationship of the jointly defined goods plays a role when analyzing free-rider behavior. The extent of free consumption associated with institution building is inversely related to the proportion of private outputs (selective incentives) involved in a given set of socially desired rules.

13. North $1981,31$.

14. Knight 1992.

15. See Olson 1965; and Stigler 1974.

16. North and Weingast $1989,804,816,829$.

17. Root 1994, 94, 181, 190-91.

18. Beckett 1986, 10, 128, 406.

19. See Carruthers 1996, 88, 201-202; and Cain and Hopkins 1986.

20. See Olson 1965; Hardin 1982; Cornes and Sandler 1986, 113-31; Sandler 1992; and Mishan 1969.

21. Posnett and Sandler 1986. 


\section{The Argument}

I build a case for a joint-products understanding of the rise of central banking. The argument fills gaps in the credible commitments account, which sees central banking as having an immediate positive impact on state finance and investor confidence, but neglects the free-rider problem. The solution, I argue, was to conjoin production of the public goods (government creditworthiness, more efficient fiscal policy) with the production of an excludable private good (monopoly rents), through a joint-products arrangement. Specifically, the government organized a discrete subgroup of creditors by offering significant private benefits in the form of monopoly privileges as an incentive to lobby for, and to participate in, the central bank venture. It then "taxed" this monopoly by requiring it to make subsidized loans to the government in wartime. In the exchange a manageable subgroup internalized part of the collective benefits of central banking, thereby resolving the dilemmas that normally constrain the provision of public goods to suboptimal levels.

The argument has both a demand and a supply side and so incorporates the motivations of the petitioners requesting a special bank charter as well as the grantors. On the demand side, the actors are a subset of all creditors seeking government regulation as a means to earn economic rents - a higher return, income, or profit that cannot be reduced or eliminated by the normal competitive forces in a market. The primary goal of these rent seekers, which facilitates their organization as a lobby, is the legal market restriction. The lobby expects the government to grant substantial rents on future financial transactions by promising a regulated banking cartel or a monopoly on the marketing of government bonds or both. Although the lobby may justify the scheme on the basis of the general good, since the cartel arrangement does enhance the government's creditworthiness, fiscal efficiency, and war-making capacity, these are external effects of its narrow selective incentives. Free riding is overcome through the organization of a subgroup that internalizes a share of the general benefits of institutional innovation.

The government composes the supply side, in the manner of Gary Becker, by virtue of its mandate to provide necessary public goods and its authority to limit competitive forces in a market. ${ }^{22}$ Inasmuch as government is accountable to the whole of society, it internalizes aggregate welfare, meaning that it has incentives to supply public goods and to minimize the deadweight loss of inefficient arrangements. In the case at hand, government seeks to reduce the distortions associated with financing high wartime expenditures through current taxation. The better policy is tax smoothing. Inasmuch as the government cannot obtain sufficient credit to spread the tax burden of war over time without offering the plum of a monopoly franchise, it has incentives to participate in the "credit for rents" exchange. In return the central bank agrees to lend money to the government on demand. Both sides are mutual hostages, since the government depends on the bank for its wartime borrowing, and the bank depends on the government for its monopoly rents. The bargain cannot be dissolved 
without making both sides worse off. The argument generates the following testable implications:

1. War, the main factor driving expenditures, induces governments to seek a central bank in order to pursue a policy of tax-smoothing debt finance. We should observe central bank bargains arising in the context of war.

2. A subset of society seeking excludable benefits organizes to support central banking. By extension, collective action should revolve around the regulations that redistribute wealth to the favored bank, not its public good components. Central bank charters should also jointly produce barriers to entry and fiscal public goods.

3. Political conflict is initially intrasectoral or microeconomic in nature, between rival firms in the banking industry. The central bank's privileges should provoke opposition from banking firms who are not so favored.

4. Once government limits competition, the market power of the favored bank will increase. Eventually, the privileged bank will become so dominant that it can assume true central banking functions, such as monetary management and lender-of-last-resort activities.

5. Macroeconomic capabilities, born of monopoly, ultimately change the character of central bank politics. As the central bank gains monetary leverage, intersectoral political divisions supersede intrasectoral rivalries. Rent seeking gives way to economy-wide controversies over the aggregate price level and the exchange rate-issues with far-reaching distributional consequences that cut across occupational lines (for example, creditors versus debtors and tradables versus nontradables producers).

In the empirical analysis to follow I present evidence regarding these expectations. Before turning to this exercise, however, I sketch a related puzzle concerning the cross-national diffusion of institutions that improve a state's capacity to mobilize resources for war.

\section{The Diffusion Conundrum}

If domestic institutions are shaped by international competition, why do institutional innovations that provide a competitive advantage in this struggle for power not diffuse readily to other states? The microfoundations of a diffusionary expectation are surely in place. Just as the organizational structure of firms is determined by exigencies of the market and technologies of production, domestic institutions should likewise be highly respondent to international competition. ${ }^{23}$ Like poorly adapted firms, states whose organization consistently yields less than optimal international performance should reform or face elimination. Yet as comparisons of early modern states plainly suggest, suboptimal institutions do survive for very long periods. England 
TABLE 1. Central banks before 1900

Nation

Bank

Date founded

Sweden
England
France
Finland
Netherlands
Austria
Norway
Denmark
Portugal
Belgium
Spain
Germany
Japan
Italy

Sverige Riksbank

1688

Bank of England

1694

Banque de France

1800

Bank of Finland

1811

Nederlandsche Bank

1814

Austrian National Bank

1816

Norges Bank

1816

Danmarks Nationalbank

1818

Banco de Portugal

1846

Belgian National Bank

1850

Banco de España

1874

Reichsbank

1876

Bank of Japan

1882

Banca D'Italia

1893

Source: Goodhart, Capie, and Schnadt 1994, 6.

Note: The table excludes central banking institutions of the Netherlands Antilles (1828), Indonesia (1828), Bulgaria (1879), and Serbia (1883).

established the Bank of England, worked out a viable system of government credit, and brought rates of interest on state bonds down from 10-14 percent in the 1690s to 5-6 percent by the early 1700s. In France, by contrast, the monarchy's credit was impaired by frequent repudiations, proposals for a central bank were rejected, and the wars ended with the entire financial machinery in disarray. ${ }^{24}$ Despite the manifest advantages of the Bank of England to British international power, it took over a century for France to emulate Britain, and only fourteen states in total had central banks before 1900 (Table 1). Adopting the English exemplar thus appears to have been difficult. The United States, for example, built two central banks on the English model before 1840, only to dismantle them in the face of intense political opposition.

My argument about the resistance to central banking focuses on a single institutional variable: the level of domestic political centralization. Although many factors surely affect patterns of central bank diffusion, the argument that the creation and durability of a central bank depend on each party's capacity to perform its part of the bargain follows logically from the joint-products model. On the central bank's side this is not a problem, since its monopoly privileges provide it with both the incentive and the resources to pay the government for its license-granting service. The government, however, has to be able to protect and enforce a central bank cartel, a regulatory capacity that I argue is rooted in the underlying structure of the political system. Very broadly, national regulatory capability depends on the level of political centralization. In countries with centralized political systems, the strong central government will be able to impose a regulatory regime, like a monopoly central bank, on the 
entire nation. However, in nations where regulatory authority is shared with local political units-in federalist systems - central banking faces special hurdles. Political decentralization means that the national government has no monopoly over economic regulation. It has to share power with local governments that maintain some degree of regulatory autonomy. The central government thus has to compete with local governments to regulate banks, since both value regulation as a means of earning revenue to fund public goods (such as infrastructure and education, in the case of localities).

In decentralized political systems I expect a basic rivalry to develop. Local governments should oppose the encroachment of a strong central bank because the bank charters they grant will be more valuable to their holders, and thus issuing charters more lucrative for the localities, if the charters convey an exclusive right. The empirical implication is straightforward: All else equal, a nationwide central banking monopoly should be more difficult to establish and maintain in decentralized, federalist systems. In centralized systems, on the other hand, the strong political center should be able to enforce a central bank monopoly over the entire nation.

I evaluate all arguments against historical developments from 1688 to 1850 . The endpoint was selected because the rationale for central banking shifted around 1850, from war finance to more modern functions, thereby complicating the analysis. (I do, however, evaluate the process by which early central banks evolved to take on modern central banking functions.) I begin with a broad comparative analysis, utilizing qualitative data from secondary sources on (1) the association between war and the rise of central banking, (2) the character of central bank charters and the presence of jointly produced public and private goods, (3) the evolution of bank monopolies into modern central banks, and (4) the political centralization of nations and the patterns of diffusion. Following this overarching review, I conduct a fine-grained evaluation of early central banking developments in England and the United States, utilizing qualitative and quantitative techniques, when possible. These cases encompass variation on a key explanatory variable, the level of political centralization, and are examples of the dominant, yet incomplete, "credible commitments" approach.

\section{Historical Patterns in Central Banking}

The forerunners of modern central banks were not born of the need for monetary services or a lender of last resort. Instead, their primary impetus was to improve governments' abilities to issue debt in wartime. Given the temporary nature of war, and the efficiency of spreading its costs over a longer period through debt finance, it was rational for states to consider chartering special banks as havens for additional government debt. Economic historians have indeed found war finance to be the main factor in the rise of early central banks. ${ }^{25}$ These banks were required to invest their capital in government bonds, and it was "this investment ... that provided much of 
the incentive to governments to found these banks in the first place." 26 Thereafter, governments came to rely on these special banks for financing deficits generated by war or by civil strife.

In fact, all such central banks in existence before 1850 were chartered in the context of war (Table 2). Some, such as the Swedish Riksbank, the Bank of England, the Bank of France, the Bank of Finland, the Bank of the Netherlands, and the Bank of Portugal, were established in the midst of war. Others, such as the First and Second Banks of the United States, the Austrian National Bank, the National Bank of Norway, and the National Bank of Denmark, were set up in the immediate aftermath of war. For banks chartered after a war the context was usually very high inflation generated by governments' overissue of paper currency to meet wartime expenditures. For example, in America, policymakers used the inflation tax to finance a large part of the War of Independence and the War of 1812, as did officials in Austria, Norway, and Denmark during the Napoleonic Wars. ${ }^{27}$ These governments subsequently chartered central banks to lend to the state and to issue banknotes convertible into specie, as a way to restore government creditworthiness and monetary stability. ${ }^{28}$

In at least two instances, however, war played a less direct role in the genesis of central banks. In Sweden, the immediate impetus was to create a successor to the nation's first and only bank, the Stockholms Banco, which failed in 1668. Yet, conforming to the pattern, the Swedish government borrowed frequently from the successor bank and did so heavily during wartime. During the Swedish war with Russia (1741-43), for example, the Riksbank's loans to the government amounted to more than three-fourths of its assets. ${ }^{29}$ In Holland, war and the French occupation so thoroughly disrupted Dutch trade and international financial leadership that King William I founded a national bank primarily to help regenerate these activities. Yet, again, the new bank served as the central government's fiscal agent from the start. ${ }^{30}$

These data support a relationship between war, public finance, and central banking. But what of the collective dilemmas involved in founding a central bank? My expectation is that private, selective benefits were needed to induce societal participation in the institutions. Evidence drawn from central bank charters is supportive (Table 2). The privileges varied, but central banks were typically given a monopoly of note issue. This monopoly was crucial to earning rents, since the majority of bank liabilities in this era were in the form of notes, rather than deposits. Thus, "a monopoly of note issue meant a virtual monopoly of commercial banking facilities." 31 The central bank's special relationship with the state provided another source of rents independent of its commercial banking activities. These banks were typically designated the sole depository of government funds and were not required to pay interest

26. Goodhart, Capie, and Schnadt 1994, 7.

27. See Timberlake 1993; Goodhart, Capie, and Schnadt 1994, 5; and Pohl 1994.

28. Goodhart, Capie, and Schnadt 1994.

29. Olsson 1994, 990.

30. de Vries 1994, 743.

31. Goodhart 1995, 205. 


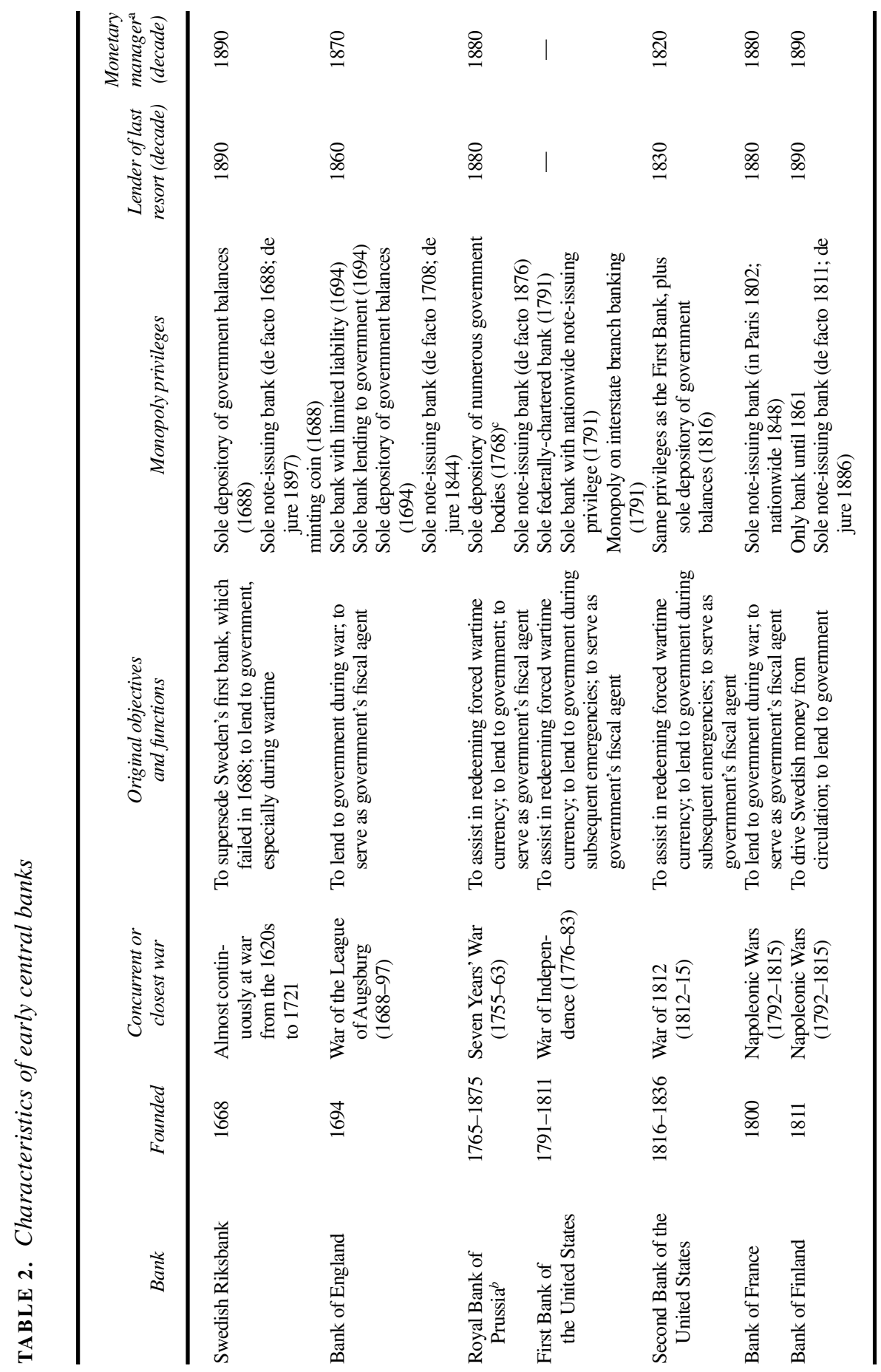




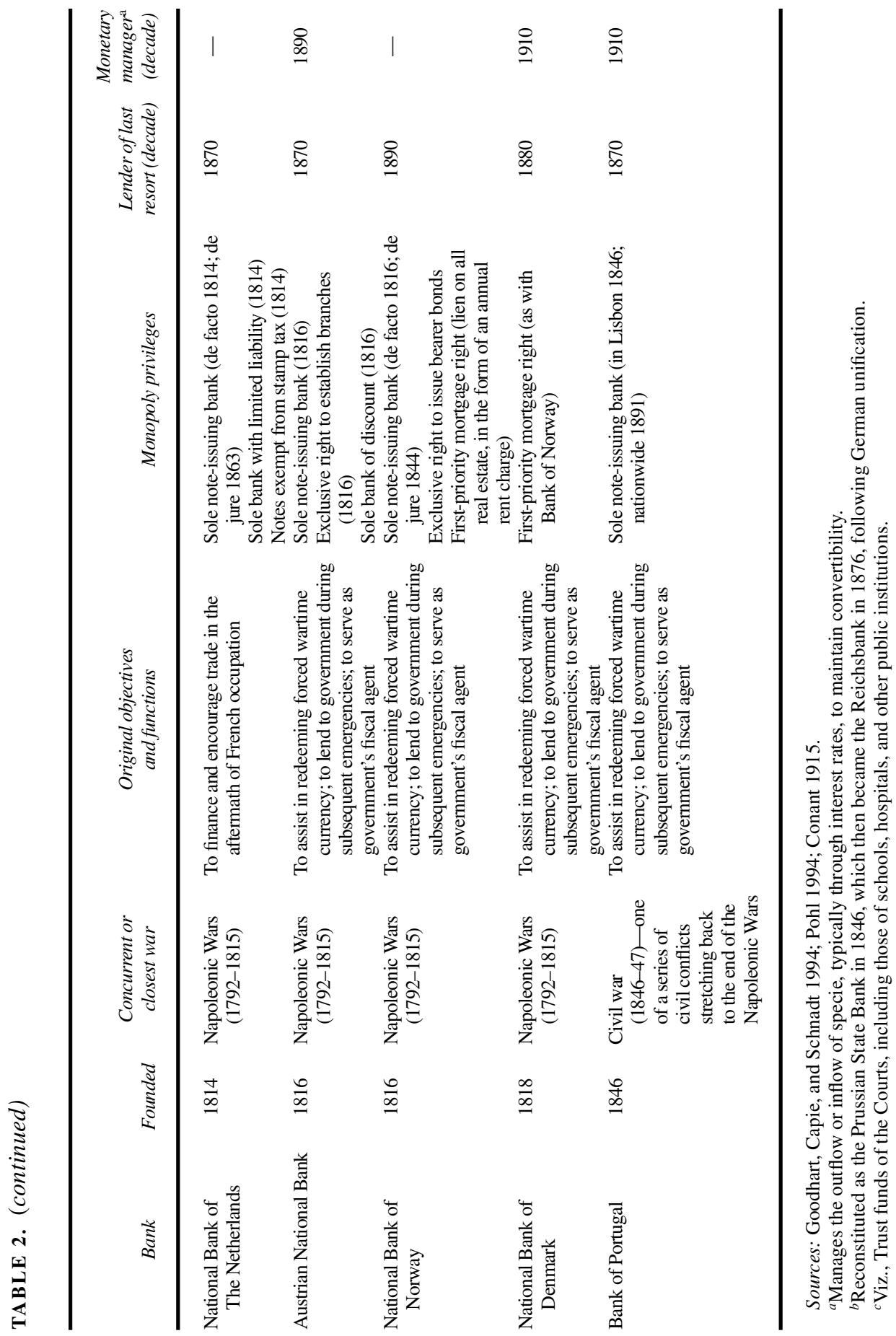


on these balances. They were usually also given the exclusive position as fiscal agent to the government, which, in addition to supplying funds, meant management of the national debt and handling the government's accounts. Since the government was the single largest transactor in the market, exclusive management of the government's accounts was likely a source of rents to the licensed bank..$^{32}$

The evolutionary consequence of granting privileges to a single bank also follows the predicted pattern. With such important monopoly rights-and the incentive to employ them to undermine competitors-special banks rose more or less steadily to a position of hegemony in their respective financial systems ${ }^{33}$ From their privileged position as monopolist note issuer and banker to the government, they attained a size and security no other bank could match. This, in turn, encouraged other banks to use the chief bank's notes as reserves. The end result of this centralization of reserves was the same in all countries: the central chartered bank made the gradual transition from a mere privileged institution into a recognizable central bank. As banking systems came to use the bank's notes as the principal reserve medium, it became possible for this dominant bank to control total reserves. With this came gradual acceptance of the role of lender of last resort. In addition, the centripetal forces generated the means and motivation for the chief bank to undertake the responsibility for the maintenance of the gold standard, the continued convertibility of bank notes and deposits into gold. During the nineteenth century, one special bank after another found itself acting as a "banker's bank," ensuring banking and monetary stability under the gold standard (Table 2). ${ }^{34}$ Walter Bagehot's observation on the rise of modern central banking in England applies generally: "With so many advantages over all other competitors, it is quite natural that the Bank of England should have outstripped them all.... Thus our one-reserve system of banking was not deliberately founded upon definite reasons; it was a gradual consequence of many singular events, and of an accumulation of legal privileges on a single bank." 35

Whereas England embarked down this path at an early date, the diffusion of central banking to other countries was slow and uneven. Yet the pattern of diffusion appears related to the degree of political centralization. Centralized and semicentralized countries had the earliest note-issuing central banks (Sweden 1668, Britain 1694, France 1800, Finland 1811, Netherlands 1814, Austria 1816, Norway 1816, Denmark 1818, Portugal 1846, Belgium 1850, Spain 1874, and Germany 1876), whereas federal democracies had very late central banks (Switzerland 1905, Australia 1911, United States 1913, and Canada 1935). More compelling is evidence that in decentralized nations, resistance to central banking hinged on the rivalry between local and national governments over the authority to charter and tax banks.

In decentralized Switzerland, for example, cantons chartered banks, and regional sovereignty allowed for the rise of thirty-four individual cantonal banks of issue by

33. Ibid.

34. Goodhart 1988.

35. Bagehot [1873] 1979, 66-67. 
$1881 .^{36}$ The Swiss constitution even protected against a monopoly central bank by the provision that federal legislation regarding banks "shall not establish a monopoly of issue of bank bills nor decree their obligatory acceptance." ${ }^{37}$ However, when the cantonal banks repeatedly failed to effectively coordinate during banking and monetary crises, a movement to establish a nationwide central bank began. Although the constitution was amended to allow the Federal Council control over note issue, it took "twenty years fighting in Parliament between radicals, wanting a purely state bank, and the conservatives who wanted a federal bank, to reach the eventual central bank compromise [in 1905]." 38

Evidence from countries that moved from decentralized to centralized political systems also supports the argument. In Germany before unification, the states chartered banks. There were thirty-three banks of issue in existence in the states in 1871, the largest being the Royal Bank of Prussia. According to pattern, "many of these banks were born of the financial necessities of the governments by which they were chartered and were under obligations to aid the public Treasury." 39 With the formation of the German Reich in 1871, the central government centralized the monetary system. The Reich simply directed the Royal Bank of Prussia to cease operations and transfer its rights and privileges to the new imperial Reichsbank. The German states, however, did not give up their regulatory rights easily. The Reich was required to pay a lump sum indemnity of $\$ 3.75$ million, as well as fifty annual payments of $\$ 465,000$ to the government of Prussia, as compensation for the loss of its rights. ${ }^{40}$

In Italy, despite the gradual political centralization, regional loyalties remained strong, especially when it came to chartering banks. "The power of regional interests remained so strong that despite the merger of the Banca Nazionale with the two Tuscan banks of issue, to form the Banca d'Italia [in 1893], the Banco di Napoli and the Banco di Sicilia were retained as separate banks of issue." ${ }^{41}$ Regional banklicensing authorities would not accept a single central bank of issue, so the government proclaimed an association, or consortium, of six banks of issue.

Although these admittedly incomplete data are consistent with my arguments, they hardly qualify as definitive proof. Evidence drawn from England and the United States adds further support.

\section{The Bank of England}

Prior to 1689 , repeated violations of government loan contracts by militarily insecure and fiscally strapped monarchs severely limited the creditworthiness of the English state. Nearly continuous war created intense financial problems for the state, which

36. Landmann 1911, 30-31.

37. Conant 1915, 269.

38. Goodhart 1988, 112.

39. Conant 1915, 187.

40. Ibid., 197.

41. Goodhart 1988, 131, 133. 
responded by acceding to the plan of a small group of creditors, seeking important monopoly privileges. In exchange for monopoly rights in government issues and banking, the Bank lent money to government at preferential terms. As predicted, the Bank's early political history revolved around its monopolistic position-intrasectoral conflict predominated in the eighteenth century. Over time, and as a result of the government's ability to retain and extend the Bank's monopolistic privileges, the Bank became a modern central bank, able to affect monetary conditions. This led to wider, intersectoral conflicts over the monetary orientation of the central bank.

The Bank of England was established in 1694 in the midst of a major war with France. At the time the government was a poor credit risk due to previous debt repudiations and confiscations of wealth. ${ }^{42}$ Creditors were wary about loaning to the government at a time when war with France required ever-higher government expenditures. In 1692, for example, a life annuity, paying a tempting 10 percent, brought in only $£ 108,000$ of an intended $£ 1$ million loan. This failure led the government to boost the interest payment to 14 percent, but the offering still remained undersubscribed. ${ }^{43}$

In 1694, with the war effort languishing for lack of funds, Parliament accepted the plan for a Bank of England, put forth by Scottish entrepreneur William Patterson. Patterson represented a small coterie of London creditors, "that powerful group in the background," whose intention was to get an inside track on the business of financing the government and commercial banking. ${ }^{44} \mathrm{~A}$ deal was cut: the state received badly needed loans in exchange for granting extensive legal privileges to a private banking corporation.

Patterson's plan invited subscribers to a loan to the Exchequer of $£ 1.2$ million to incorporate the Bank of England. In other words, the Bank was founded with a capital of $£ 1.2$ million, which was immediately lent to the government. The loan was a perpetuity, paying 8 percent interest plus $£ 4,000$ annually in management fees. In return the Bank's subscribers received the following rights: (1) The exclusive right to manage all government loans, (2) the exclusive right to lend money to the government, (3) the right to form a joint-stock banking company, (4) the exclusive privilege of limited liability in banking, and (5) the right to issue banknotes backed by government bonds, to the amount of the Bank's capital.

In contrast to previous debt offerings, this loan was fully subscribed within ten days. ${ }^{45}$ Why did this debt scheme work so well in attracting participation? If the founders and subscribers of the Bank were motivated by supernormal profit considerations, their participation makes sense. Since the subgroup involved in the Bank obtained privileges that would give them superiority over all competitors in both public finance and in the general banking business, it was rational to contribute. Consider the following incentives: (1) The exclusive right to hold all government loans meant that the Bank had a lock on managing the government's finances-a

42. Dickson 1967.

43. Macleod 1923, 445-46.

44. Clapham 1944, 15.

45. Ibid., 19. 
very large business - and, thereby, earned commissions and fees that in a free market setting would have been allocated competitively; (2) the exclusive right to lend money to the government gave the Bank a similar advantage over rivals as originators of loans; (3) the right to form a joint-stock banking company, combined with (4), the exclusive privilege of limited liability in banking, meant that, among all financial firms, the Bank's shareholders were liable for the debts of the Bank only to the amount of their investment, and not for its entire liability; (5) most importantly, the right to issue banknotes meant that the Bank was able to loan money in excess of deposits, by reason of the circulating notes it could issue against the government debt. ${ }^{46}$ On the assumption that $£ 1.2$ million in banknotes could be loaned to private borrowers at the same rate as the government ( 8 percent), the Bank earned $£ 96,000$ from private borrowers, in addition to the $£ 100,000$ from the government, for a total return of 16.33 percent on its capital. Hence, the "precise purpose which the Government had in view in permitting their circulation [that is, the circulation of Bank of England notes] was that of subsidizing the banker in return for the facilities he provided." 47 The Bank's goldsmith-banker competitors, by contrast, were not only excluded from government lending and financial management but restricted to deposit banking, which meant lending coin or credit for which they held coin in reserve. ${ }^{48}$

As expected, opposition came from rival creditors who felt that the legal advantages allotted to the Bank gave it a superior competitive position: "The new Bank had to meet the opposition of the goldsmiths and money-lenders who were deprived of their most obvious profits by the new undertaking." 49 According to John Brewer, "Ever since the foundation of the Bank of England ... political and economic interests excluded from participating in state financing complained bitterly about the special advantages enjoyed by holders of the public funds and tried to muscle their way into the action. ... The prospect of financial hegemony in both the public and private spheres was the glittering prospect offered by corporate dominance of the national debt." 50

War was the usual context in which the Bank's charter was renewed. From 1688 to 1815 , England was involved in seven extended wars, as well as other military crises, such as the Jacobite uprisings of 1715 and 1745. For most of the Bank's first 120 years, the nation was "either preparing for war, waging war, or seeking retrenchment after war," and the Bank's future was always negotiated during a military emergency. ${ }^{51}$ The terms of each charter never extended for more than twenty-nine years, and on each occasion provision was made for the expiration of the charter twelve months after a given date. "This brought a particular pattern of development to the Bank that was ultimately dependent upon the rhythm of war and peace ... the Bank

46. Ibid., 21-22.

47. Powell 1966, 126.

48. Conant 1915,84 .

49. Andreades 1924, 68.

50. Brewer 1988, 120, 122.

51. Bowen 1995, 5 . 


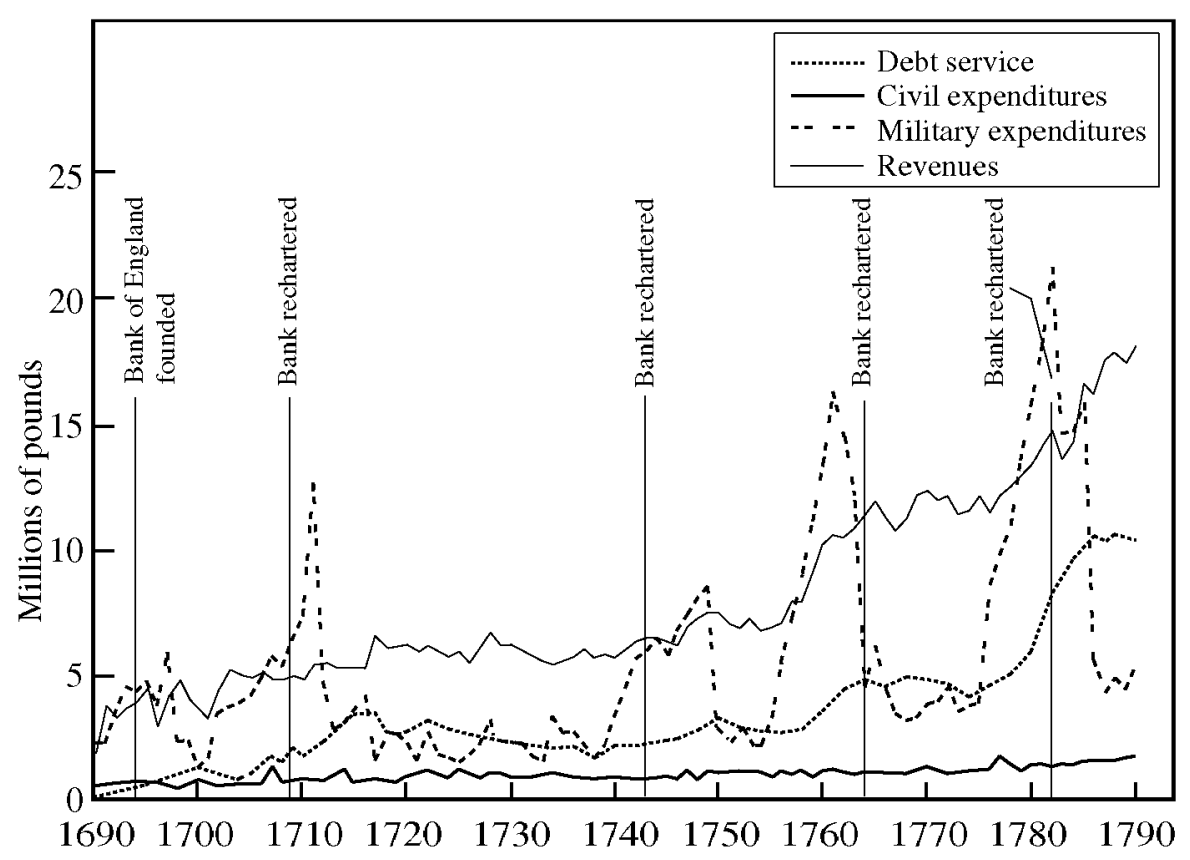

FIGURE 1. British spending and revenue, 1690-1790

Source: Brian R. Mitchell, British Historical Statistics (Cambridge: Cambridge University Press, 1988), $575-80$.

needed the state [for rents] as much as the state needed the Bank [for public finance]." 52

This pattern is depicted in Figure 1. The spikes in military spending reflect periods of war, and by virtue of the twelve-month clause, the Bank's charter was always renegotiated during war. This flexibility gave the government the ability to extract "payment" from the Bank for protecting it at precisely the time when government needed funds the most. In return the Bank secured greater monopoly powers.

The bargain was renewed repeatedly, despite the opposition of competing financial interests. In 1695, these competitors lent their support to the scheme of a Land Bank, which was chartered, but never began operations, because the promoters failed to raise the funds for its cheap loan to the government..$^{53}$ The Land Bank challenge prompted the Bank to negotiate a series of agreements with Parliament, the principle in each case being that in return for subsidized loans "no other Bank or Constitution in the nature of a bank be erected or established, permitted or allowed by Act of 
Parliament during the Continuance of the Bank of England." 54 The Bank simply "wanted no more Land Banks." 55 In addition to obtaining a genuine legal monopoly, the Bank was exempted from paying taxes and received an extension of its other privileges. ${ }^{56}$

In 1708, during a war with Louis XIV, and again in exchange for cheap loans, the Bank obtained its most significant barrier to entry-the legal prohibition of associations of more than six individuals from carrying on a banking business in England. This was crucial in restricting competition, because issuing banknotes was the major source of bank funding in this era. ${ }^{57}$ The Act of 1708 thus gave the Bank "a monopoly over joint-stock note issue." ${ }^{58}$ Despite the lack of a ban on joint-stock deposit banking, "the intention was to give the Bank of England a monopoly of joint-stock banking, and had any other institution of more than six partners attempted to carry on a banking business in England . . . it would have been suppressed." 59

The Bank regarded its paper currency monopoly as critical to its profitability and was willing to make large financial concessions to the government in order to protect and extend it. The government, in turn, was willing to grant the Bank a monopoly, because it needed the Bank's assistance to help it finance frequent foreign wars. Just prior to the expiration of its charter in 1742, the Bank provided an interest-free loan to the government in return for receiving a confirmation of its monopoly powers (the privilege of issuing circulating notes was reinforced) and a lengthening of its charter to 1764. In that year the Bank gave the government a gift of $£ 110,000$, plus a cheap loan at 3 percent. In 1781, another extension was granted in return for yet another subsidized loan, giving the Bank a charter until 1812.

That the Bank's shareholders repeatedly provided subsidized credit to the state is evidence of the private benefits (rents) they expected to earn from the artificial barriers to entry the government provided. From the shareholders' perspective, monopoly privilege had a price. Not all the gains of this institutional arrangement were private and distortionary, however. The government and society at large also benefited, by way of more efficient fiscal policy. ${ }^{60}$ As a consequence of the Bank's ability to enforce a credit boycott (along with new parliamentary provisions for financing debt service), the sanctity of government loan contracts improved markedly. And with creditors' rights more secure, the government was able to borrow to finance wars on a scale that the Stuarts could only dream of. By 1720 , government debt was over fifty times the 1688 level. ${ }^{61}$ Moreover, the costs of borrowing also fell markedly, from 14 percent in the early 1690 s to 3 percent by the 1730 s, indicating that the risk of lending to the state had fallen. Thus the state's ability to finance wars by pursuing a

54. Clapham 1944, 47.

55. Ibid.

56. Andreades 1924, 111-12.

57. White 1989, 73.

58. Russell 1991, 43.

59. Feavearyear 1963, 167-68.

60. North and Weingast 1989.

61. North and Weingast 1989, 822. 
policy of tax smoothing (a public good) went hand-in-hand with the rent-seeking origins and expansion of the Bank of England.

The public good of more efficient tax policy is shown graphically in Figure 1. That government revenues do not spike upward with every increase in military expenditures reflects the state's improved access to debt finance. In lieu of raising taxes to finance wars, the government borrowed, as seen by the corresponding increase in debt service. Although this was efficient in the sense that it reduced the distortions of financing massive military undertakings, it came at the cost of having foisted a dominant bank onto an embryonic financial structure.

Since the only banks not affected by the Bank of England's monopoly were those having less than six partners, weak banks proliferated in the provinces to meet the demand for banking services. In 1750 there were only about twelve banks outside London, but by 1790 the number had risen to around four hundred. These deposit banks tended to collapse at the first unusual demand for cash. The panics of 1793, 1797,1810 , and 1812 were "due to the defective organization of the provincial credit," which itself was a direct result of the monopoly powers of the Bank of England. ${ }^{62}$ "The six-partner rule prevented England from experiencing the rise of strong nationally based joint-stock banks such as those whose branches superseded local and private banks in Scotland." 63 The centralization of banking privileges thus had its costs, as one would expect: "(1) The banks outside of London were artificially stunted and failure-prone; and (2) the Bank of England as sole London issuer occupied a position of unrivaled hegemony over the currency system as a whole." ${ }^{64}$ It was this second distortion that transformed the Bank of England into an institution with monetary powers - a true central bank - and so reshaped political divisions.

With its accumulated monopoly rights, the Bank of England obtained the power to affect general credit conditions, a power of which the government took advantage during the Napoleonic Wars; it pressured the Bank to help finance the wars through inflation. This form of expropriation, however, had more general macroeconomic effects, adding a new dynamic to the politics of central banking. No longer were the battles primarily between the Bank and other less privileged financial firms. Since the redistribution was intersectoral, political alignments followed suit, with divisions between creditors and debtors, and tradables and nontradables producers, being preeminent.

During the Bank's first century, its ability to impart discretionary monetary influence was constrained by a gold standard rule, wherein the Bank pledged to redeem its bank notes at a fixed price in gold. If notes were over-issued, causing their market price in terms of gold to fall below the promised price, people would arbitrage the difference by trading gold for notes in the market at the low price and exchanging the notes for gold at the Bank at the higher price. Specie convertibility, in short, acted as the dominant constraint on note issue. For the century in which this mechanism was 
in place (1694-1793), the rate of inflation in England was statistically indistinguishable from zero. ${ }^{65}$

In the early stages of the Napoleonic Wars, however, the Bank suspended gold payments, due to pressure from the government to finance the war effort. ${ }^{66}$ Suspension lasted from 1797 to 1821, and in the interim the Bank became little more than the monetary arm of the Exchequer. ${ }^{67}$ The result was inflation and the depreciation of sterling against other currencies. The Bank thereby usurped the property rights of all persons whose wealth consisted of money. In addition, depreciation worked to the advantage of tradables producers by raising the prices of traded goods relative to nontradables. This set the stage for intersectoral conflict over the terms of the monetary settlement.

Suspension had general political ramifications because its consequences, inflation and depreciation, brought about a redistribution of wealth from all creditors and producers of nontradable goods to all debtors and tradables producers. ${ }^{68}$ No longer was the Bank controversial because its legal monopolies privileged one group of creditors against all others. Since its notes were now fiat currency and the government financed much of the war through inflation, two large intersectoral coalitions formed. The key beneficiaries of suspension were farmers and manufacturers. Tenant farmers found strong incentives to support the existing state of monetary affairs, since "the price of the farmers' crops was rising whilst they were continuing to pay the same rents in depreciated notes." ${ }^{69}$ The price of wheat jumped from $6 \mathrm{~s} .9 \mathrm{~d}$. per bushel in 1797 to 16s. in 1800, while rents on agricultural land remained fixed at preinflation levels by long-term leases..$^{70}$ Farmers and debtors of all classes gained from suspension, since they made interest and principal payments in a currency worth about 17 percent less in gold than when their debts were contracted. ${ }^{71}$

Manufacturers and industrial labor sided with farmers, since industrial demand, prices, and wages all rose as a result of the depreciation of sterling and the general stimulus of war. ${ }^{72}$ The expansion, however, brought price, profit, and wage levels that were difficult to sustain after the final defeat of Napoleon. With war's end, demand dropped off, import competition increased (as blockades were lifted), and prices fell. Birmingham industrialists aligned with farmers in seeking monetary relief from deflation-appreciation. ${ }^{73}$ In addition, "the great exporting centers [such as Manchester] were just as antagonistic." 74 The coalition's anti-gold standard platform alternatively called for the continuation of suspension or a return to gold convertibility at a rate substantially lower than the prewar level because "depreciation would

65. Santoni 1984, 19.

66. See Feavearyear 1963, 179-83; and Morgan 1943, 23-24.

67. Andreades 1924, 195-202.

68. Frieden 1991.

69. Andreades 1924, 236.

70. Ashton 1959, 181.

71. Andreades 1924, 237.

72. Morgan 1943, 23-48.

73. See Hilton 1977, 31-97; Fetter 1965, 73-76, 99-106; and Feavearyear 1963, 224-26.

74. Hilton 1977, 57. 
effect a redistribution of wealth in favour of the productive classes-manufactures, merchants, and farmers." 75

In contrast to farmers and manufacturers, depreciation harmed England's creditor and rentier groups. "A creditor of 1800 might, because of the depreciation, be a debtor in 1819, and consequently be twice legally robbed." 76 David Ricardo laid out the "universal" principle: "Every man is injured or benefited by the variation of the value of the circulation in proportion as his property consists of money, or as the fixed demands on him in money exceed those fixed demands which he may have on others." 77 The position of the landed aristocracy is instructive. From the late seventeenth century, landlords built ever-larger estates and rented their acres to tenant farmers on long leases. ${ }^{78}$ But during the inflationary war years, landlords received only about two-thirds of their rent in real terms. ${ }^{79}$ Unable to raise rents in line with the upward trend in commodity prices, and prevented by Parliament from requiring tenants to pay rents in gold, landed elites wanted deflation and an early return to the gold standard. ${ }^{80}$

Growing numbers of government bondholders joined landlords in supporting the gold standard. Bonds had been issued in vast quantities to finance the wars, at a time of high prices and interest rates. ${ }^{81}$ By war's end there were roughly seventeen thousand of these "fundholders." 82 Depreciation reduced the purchasing power of bond dividends and, through the rise in interest rates, reduced their capital value as well. ${ }^{83}$ If the trend were reversed, bondholders, who had bought into the national debt with depreciated currency, would receive repayment in a currency with much greater purchasing power. In effect deflation would produce a large bonus for this group as the real value of the war loans and interest payments rose. Indeed, after resumption of gold payments in 1821 , interest on the war debt came to absorb over half the government's total revenue by 1827 , redistributing wealth from taxpayers to investors.

Collective action problems should have constrained the political capacities of both coalitions, consisting, as they did, of large numbers of individuals. To some extent this is accurate, since the parliamentary debates surrounding Peel's Act of 1819 (which officially reestablished the convertibility of Bank of England notes into gold at the prewar rate) show little in the way of mass political pressures. Four classes of witnesses, weighted heavily toward the financial community, appeared before the Bullion Committee in 1810: Bank of England directors, private bankers, merchants, and political economists. The entire gold standard coalition might have been "privileged" by the existence of a single dominant creditor-the Bank of England itself-an Olsonian interpretation consistent with the view that "the gold standard

75. Ibid., 63.

76. Ibid.

77. Ricardo [1816] 1951, 136-37.

78. Tracy 1989, 37.

79. Andreades 1924, 237.

80. Conant 1915, 111.

81. Johnson 1970, 38-39.

82. Jenks 1924, 26.

83. Keynes 1924, 7-21. 
came about largely as a result of the Bank's continuous prods to an unwilling Parliament." ${ }^{84}$ Moreover, if the large bonus the Bank stood to gain from having its outstanding government loans revalued is considered a form of rent, the argument is even stronger, for here, too, institutional creation hinged on narrow private motivations. While the Act of 1819 benefited all creditors by limiting the Bank to issue notes only in relation to the ebb and flow of gold, this protection may have come about as a secondary consequence of the rent-seeking behavior of the Bank.

In summary, the collective dilemmas British society faced in the early 1800 s were fundamentally different from a century earlier. In the 1690s the problem was government opportunis $m$ in relation to its debt obligations; in the latter period it was government opportunism in relation to its currency obligations. Paradoxically, the solution to the first problem created the second. As the Bank of England grew in relation to other banks on its anticompetitive foundations, it gradually assumed central bank capacities, which the government seized during the Napoleonic Wars, and depreciated the currency. To limit future recourse to this option, lenders and landlords, perhaps privileged by the position of the Bank in credit and capital markets, rallied to obtain a legal commitment to the gold standard.

\section{The First Bank of the United States}

Early central banking arose in the United States during the War of Independence, after the fledging government undermined the sanctity of its debt obligations and its monetary covenant with citizens. Unable or unwilling to raise taxes to finance the war, the Continental Congress took to the printing press to outfit the army, and the resulting depreciation destroyed confidence in both the government's credit and paper money. As in Britain, a bargain was struck. The government promised rents on financial transactions to a special bank by granting it a monopoly on national banking and government debt management. In return the bank agreed to lend its capital to the government. The exchange took the form of the charter of the First Bank of the United States and had the positive effect of restoring public confidence in lending to the government and the currency. The First Bank also developed into a central bank with regulatory powers, again largely due to its legal privileges. Yet, unlike the Bank of England, America's first central bank could not perpetuate itself. When the First Bank's rechartering effort failed in 1811, confidence problems in debt and money reappeared, severely constraining the government's ability to prosecute the War of 1812. This wartime crisis brought forth a successor bank-the Second Bank of the United States-but like its predecessor, it too was politically unsustainable.

For these developments to fit the theory, the following should be observed: (1) rent seeking should have been elemental to the origins of the central bank, and (2) the central bank exchange should have been durable only so long as the government was able to maintain the bank's cartel. I propose that dissolution occurred in the United 
States due to strong federalism, which gave state governments the power to charter banks, creating conflict between rival licensers of banking monopolies.

During the War of Independence, the Continental Congress issued \$242 million in "Continentals," and the states issued their own paper to the amount of \$209 million; all this superimposed over a preexisting money supply of only $\$ 12$ million. About 85 percent of the war was financed by issuing unsecured paper money. Taxation was limited, because Congress lacked the legal authority and the infrastructure to tax. Like Parliament under William Pitt, Congress used its monetary powers as a critical source of war finance. In both cases war was the catalyst for institutional change, since it led to fiscal and monetary disturbances (inflation in the British case, hyperinflation in the American case) that brought central banking to the political foreground.

Since currency was issued far in excess of any increase in specie, prices rose sharply. By 1781 the phrase "not worth a Continental" was common currency. ${ }^{85}$ For people with property in the form of money, the effects of the price inflation were severe. Since the paper was granted legal tender status, the fall in its purchasing power had the usual effect of transferring wealth from creditors and people on fixed incomes to debtors. Debtors of all kinds-frontier farmers, manufacturing entrepreneurs-scrambled to repay their obligations in the nearly worthless money, while creditors took to hiding out to avoid receiving repayment in the depreciated notes. ${ }^{86}$

As in England after 1815, generalized conflict over money followed. Creditors and rentiers wanted a paper currency only if it was convertible into specie, so as to avoid receiving interest and principal payments in money of inferior purchasing power. Holders of public securities were particularly interested in deflation and stable money, since the bonds and certificates of indebtedness they held would rise sharply in value if made payable at their full face value in currency redeemable in specie. Moreover, speculators picked up these securities at large discounts on the gamble that interest and principal would be repaid at par and in specie. ${ }^{87}$ The creditors of the American Revolution, just like the creditors of George III, stood to receive a hefty premium from monetary orthodoxy.

Stable money advocates were creditors of the states and the new national government, as well as speculators who believed that the new government would have to honor all wartime commitments in hard money or seriously weaken its credit standing. For the young government, the need to enhance public credit was critical, due to the war emergency. Alexander Hamilton saw the Bank of England as the model for building credibility: "There is no other [institution] that can give to government that extensive and systematic credit which the defect of our revenues makes indispensably necessary to its operations. ... Great Britain is indebted for the immense efforts she has been able to make, in so many illustrious and successful wars, essentially to that vast fabric of credit raised on this foundation." 88 
Hamilton proposed a central bank with special privileges (along with mechanisms for funding the public debt). Earning rents in banking was again the selective incentive that motivated individuals to participate in the project. Like the Bank of England, the design of the First Bank served to enshrine it both as the dominant bank in the nation and as an important fiscal aid to the government. Like its English counterpart, the First Bank also acquired so much business that its "public [fiscal] function was to many persons quite unapparent except as usurpation and privilege." ${ }^{99}$ From the start, opposition was based on the First Bank becoming a "government subsidized monopoly designed to benefit only a small part of the population." 90 Nevertheless, the First Bank did grant fourteen loans totaling \$13.7 million to the Treasury, and assisted in both the collection of taxes and the administration of public finances..$^{91}$ By allowing subscribers to pay for their capital stock one-fourth in specie and three-fourths in government securities, the First Bank not only attracted sufficient capital to support extensive lending operations but also enhanced the market price of government bonds and, thereby, improved public credit.

For Hamilton the "national bank was an institution of primary importance to the prosperous administration of the finances, and would be of the greatest utility in the operations connected with the support of the public credit." 92 In future wars the government could look to the First Bank, rather than to the printing press, for finance. In addition to taking government debt, it would also serve as the government's fiscal agent, facilitating the collection of revenues and the distribution of expenditures. ${ }^{93}$ But the First Bank's artificial advantages, not its public functions, were the sufficient conditions for its establishment.

The First Bank was given an exclusive national charter; Congress could authorize no other bank during the First Bank's twenty-year charter. Because it was the only national bank, the First Bank's note issue had a national character that other banks could not match. ${ }^{94}$ Additionally, it had a lock on the large deposits of the federal government. And by virtue of its right to establish branches (eight were established), the First Bank was the only banking firm that could operate throughout the nation. These special advantages were necessary to cajole participation in the scheme. The inducement was the possibility of earning rents, not the nonexcludable fiscal benefits of the plan. Indeed, the First Bank's initial public offering of $\$ 8$ million was heavily oversubscribed within an hour. ${ }^{95}$ The demand was so heavy that trading in bank subscription certificates followed, and the original \$25 certificates soared to over $\$ 300 .{ }^{96}$

Hamilton saw the need to grant concessions to participants in the project: "Those who are most commonly creditors of a nation are enlightened men ... enlightened

89. Hammond 1957, 249.

90. Morgan 1956, 474.

91. Wettereau 1937, 270.

92. Annals of Congress 1790, cited in Rowe 1965, 9.

93. See Timberlake 1993, 4-11; and Holdsworth 1910.

94. Redlich 1968, 98.

95. Wettereau 1937, 273.

96. Ibid., 275. 
friends of good government ... who took the risks of reimbursement, a hazard which was far from inconsiderable ... and each security holder deserved to reap the benefit of his hazard." ${ }^{97}$ Furthermore, Hamilton acknowledged the First Bank's joint private and public outputs and the role selective incentives played in making the venture work. In his "Report on a National Bank," Hamilton wrote: "The operation presents, in its outset, a very considerable advantage to those who may become subscribers; and from the influence which that rise would have on the general mass of debt, a proportional benefit to all the public creditors, and, in a sense which has been more than once adverted to, to the community at large." 98

The First Bank was good for society, for it fortified government credit and made fiscal policy more efficient. It also benefited current bondholders, especially speculators, who bought public debt at deep discounts and in depreciated currency. It was especially good for the small group of bank subscribers, since, in addition to exchanging cheap government bonds for bank stock, backers could expect to earn rents in the banking business, due to the legal advantages lodged in the First Bank. In terms of investor incentives, the public benefits were secondary to the private gains. Although Hamilton liked to argue that "public utility is more truly the object of public banks than private profit," he understood that the First Bank's monopoly advantages were behind its wild success in attracting investors. ${ }^{99}$

The First Bank's initial legal privileges were also the source of its central banking powers. Its role as financier and fiscal agent to the government, its predominance in note issue, its monopoly on interstate branch banking, and its subsequent accumulation of reserves gave it the ability to influence the money supply. The form of influence was peculiar, however, because state governments also chartered note-issuing banks (discussed later). Because the First Bank was the government's fiscal agent, it received the notes of state-chartered banks in payment for taxes. This made it the creditor of the state banks, thereby giving it claims upon them for specie. The relationship enabled the First Bank to exercise monetary control, in the manner of a central bank. Indeed, the First Bank sometimes kept state banks in line, by refusing to accept notes that were not redeemable in specie, and by returning the notes of questionable banks for redemption. ${ }^{100}$ Albert Gallatin described this central banking function as "securing with certainty" a stable currency. ${ }^{101}$

The first American central bank, like its English counterpart, came into existence to aid the government, but its charter was allowed to lapse. To explain this difference, I invoke the structure of political institutions. The federal structure of the American political system, and the consequent semisovereign powers of state governments, meant that the national government faced competition from the states in chartering note-issuing banks. The existence of state-chartered banks-and local governments fiscally dependent on them-meant that the First Bank faced powerful opponents.

97. Cited in Johnson 1970, 148.

98. Cited in Lodge 1904, 358.

99. Morgan 1956, 478.

100. See Holdsworth 1910, 51; and Timberlake 1993, 10-11.

101. Cited in Hammond 1957, 305. 
TABLE 3. Bank-derived revenue, state regulatory structure, and the House vote on the First Bank of the United States, 24 January 1811

\begin{tabular}{|c|c|c|c|c|c|}
\hline \multirow[b]{2}{*}{ State } & \multirow{2}{*}{$\begin{array}{l}\text { Bank-derived } \\
\text { revenue (\% of } \\
\text { total revenue })^{\mathrm{a}}\end{array}$} & \multirow{2}{*}{$\begin{array}{l}\text { First Bank } \\
\text { branches }^{\text {b }}\end{array}$} & \multirow{2}{*}{$\begin{array}{l}\text { Regulatory regime } \\
\quad \text { (first year) }\end{array}$} & \multicolumn{2}{|c|}{$\begin{array}{l}\text { House vote on the } \\
\text { First Bank (count) }\end{array}$} \\
\hline & & & & Against & For \\
\hline Pa. & 0.48 & Philadelphia (main office) & equity (1793) & 16 & 4 \\
\hline Mass. & 0.38 & Boston (1792) & equity (1793) & 6 & 7 \\
\hline Md. & 0.26 & Baltimore (1792) & equity (1793) & 3 & 3 \\
\hline Va. & 0.11 & Norfolk (1799) & equity (1804) & 12 & 8 \\
\hline S.C. & 0.06 & Charleston (1792) & equity (1803) & 6 & 0 \\
\hline N.Y. & 0.06 & New York (1792) & equity (1792) & 4 & 11 \\
\hline Ga. & 0.06 & Savannah (1799) & - & 2 & 1 \\
\hline Del. & 0.39 & & equity (1794) & 0 & 1 \\
\hline Conn. & 0.17 & & equity (1805) & 0 & 7 \\
\hline N.C. & 0.17 & & equity (1804) & 8 & 5 \\
\hline N.J. & 0.09 & & - & 2 & 4 \\
\hline Vt. & 0 & & - & 0 & 4 \\
\hline R.I. & 0 & & $\operatorname{tax}(1804)$ & 0 & 2 \\
\hline N.H. & 0 & & equity (1792) & 0 & 5 \\
\hline Ку. & - & & - & 3 & 1 \\
\hline Tenn. & - & & - & 2 & 1 \\
\hline Ohio & - & & - & 1 & 0 \\
\hline Mean & 0.16 & & & 65 & 64 \\
\hline
\end{tabular}

Sources: Sylla, Legler, and Wallis 1987, tab. 1; Clarke and Hall 1832, 274-75; and Holdsworth 1910, 36.

ancludes bank dividends, taxes, and bonuses paid for charters. Figures are averages for the five-year period, 1811-15. A dash indicates insufficient data.

${ }^{\mathrm{b}}$ The First Bank also had branches in Washington, D.C. (1799) and New Orleans (1804).

"An "equity" regime means partial or total state ownership of banks. A "tax" regime means the state government taxes bank capital or profits. A dash indicates insufficient data.

Although states lost the power to issue currency at the Constitutional Convention, they did not lose the power to charter banks. Like the national government, states viewed banks as sources of revenue and, therefore, coveted the power to charter them. Indeed, several states derived close to half their revenue from bank sources (Table 3). States appropriated part of the value of banking privileges and used the funds generated to finance local public goods, such as education and internal improvements. ${ }^{102}$ Since banks depended on the favor of state governments, and states depended on banks for their fiscal needs, exchanges between state governments and favored banks were common. Unlike the Bank of England's national monopoly, large banks of issue did arise in the United States, even though the First Bank operated as the only nationally chartered bank. 
States valued the power to charter banks for the same reason as national governments. These charters were in fact "virtual carbon copies of the Bank of England's charter." ${ }^{103}$ State governments received large payments, or loans on favorable terms, in return for granting monopoly rights in note issue. "The motives (and actions) of the states in this regard were similar to any license-granting monopolist ... bank charters would be more valuable to their holders, and thus issuing charters would be more lucrative for the states, if the charters conveyed an exclusive right to issue paper currency." 104 An important American variant was that state governments often required bank promoters to cede the state an equity interest in banks, in return for granting a charter, and bank dividends came to account for a substantial portion of state revenues. ${ }^{105}$ As shareholders, states "had an incentive to maximize the value of that interest by restricting competition." 106

States thus set up their own licensed banks. At first, these were monopolistic franchises that performed public services in government finance in exchange for prohibiting the banknote issue of banking competitors. In 1800 the equipoise was one, or at most, several, banks per state. By the 1830s, however, the new equilibrium was a fairly open and competitive banking industry. ${ }^{107}$ Some historians see the movement as driven by rival rent seekers. ${ }^{108}$ Yet variation in the way states regulated banks was a key factor. ${ }^{109}$ Where state governments held equity stakes in banks, their incentive was to limit new charters, since restricting competition maximized the value of that stake. In contrast, when states taxed bank inputs, such as capital, the incentive was to grant many charters, since this maximized the use of that input. Over time the trend was toward taxing inputs and, thus, toward open entry. But when the First Bank's fate was decided in 1811, the norm was still equity stakes by state governments, and a limited number of banks. ${ }^{110}$

These facets of bank regulation shed light on the First Bank controversy. Opponents mixed states-rights constitutional arguments with antimonopoly rhetoric as they railed against the First Bank's privileges. State banks largely favored renewal, but some state governments were vehemently opposed. The legislatures of Pennsylvania, Virginia, Massachusetts, and Maryland submitted resolutions opposing renewal on grounds that the right to conduct banking within their states was a state power. ${ }^{111}$ Constitutional issues aside, these states had practical reasons to oppose the national bank. Branches of the First Bank were in place in all four states, and these states were among the most dependent on banks for revenue (Table 3). They were competing head-to-head with the national government in licensing banks, and they

103. Russell 1991, 48.

104. Ibid.

105. See Sylla, Legler, and Wallis 1987, 391-403; and Fenstermaker 1965, 17-20.

106. Wallis, Sylla, and Legler 1994, 142.

107. See ibid.

108. Hammond 1957, 67.

109. Wallis, Sylla, and Legler 1994.

110. Fenstermaker 1965, 401.

111. Holdsworth 1910, 90. 
opposed the First Bank because it undercut their regulatory authority and threatened their revenue base.

To conduct a uniform test of the argument, I put "yes" votes (for renewal) over the total votes for each state delegation and then tested to see if this proportion was significantly different between states in direct regulatory competition with the First Bank and states that were not. Table 4 contains the results of a $t$-test for unrelated samples. Group 1 consists of states that housed a branch of the First Bank: Pennsylvania, Massachusetts, Maryland, Virginia, South Carolina, New York, and Georgia. Each state in this group derived a portion of its total revenue from bank regulation, ranging from 6 to 48 percent. Group 2 consists of states that had no branch of the First Bank: Delaware, Connecticut, North Carolina, New Jersey, Vermont, Rhode Island, and New Hampshire. Some states in this group derived a substantial portion of revenue from banks but did not compete directly with the central bank in licensing banks, due to the absence of an in-state branch of the First Bank. Hence, their state delegations could vote the national interest on the legislation. ${ }^{12}$ The results are compelling. In states that housed First Bank offices (group 1) the mean proportion of the delegation voting in favor of renewal was 0.38 , whereas in states where the First Bank had no branches (group 2) the mean proportion was 0.86 . The obtained $t$-value is -3.69 , which is statistically significant at the .003 level. These results support the claim that federalism was at the root of the conflict. Voting patterns in Congress differed significantly between states in regulatory competition with the First Bank and states that were not.

\section{The Second Bank of the United States}

Demand for a new central bank began only three years after the fall of the First Bank, prompted once again by the fiscal exigencies of war. When war broke out with England in 1812, the federal government was forced to conduct its fiscal policies without the aid of a national bank. The heavy resource demands caused government expenditures to increase sharply, while regular revenues (customs) declined due to embargoes. Congress attempted to finance the deficit by authorizing sales of government securities, but banks and the public shunned the offering. Without the First Bank, public creditworthiness had fallen, and the loan was subscribed very slowly. ${ }^{113}$ The government then resorted to the inflation tax to finance the war. Between 1812 and 1815 , the Treasury issued $\$ 36$ million in "notes" that were, in effect, money. Treasury notes outstanding equaled 39 percent of all bank reserves by 1813, and 65 percent by $1816 .{ }^{114}$

112. These states might have forecast future regulatory competition with the federal government, since the First Bank continued extending its branch network. However, the national financial system was so underdevelope $d$ at this time that such foresight would have required unrealistically long time horizons on the part of politicians.

113. Timberlake 1993, 14.

114. Ibid., 15. 
TABLE 4. First Bank branches and votes for renewal

\begin{tabular}{lllll}
\hline & $n$ & Mean & $S D$ & $S E$ \\
\hline GROUP 1 (branch) & 7 & 0.3843 & 0.238 & 0.090 \\
GROUP 2 (no branch) & 7 & 0.8629 & 0.248 & 0.094 \\
Mean difference $=-0.4786$. & & & & \\
\hline
\end{tabular}

t-test for equality of means

\begin{tabular}{lllccc}
\hline Variances & t-value & DF & 2-tailed sig. & SE of diff. & 95\% CI for diff. \\
\hline Equal & -3.69 & 12 & .003 & 0.130 & $(-0.761,-0.196)$ \\
Unequal & -3.69 & 11.98 & .003 & 0.130 & $(-0.761,-0.196)$ \\
\hline
\end{tabular}

Note: Data are from Table 3. $X_{1}$ : Branch First Bank $\left(1=\right.$ branch, $2=$ no branch). $Y_{1}$ : Percentage of vote for renewal (yes vote divided by total state delegation vote).

Despite the crisis, the Treasury did not organize the campaign for a new national bank. Instead, a small group of investors, led by Stephen Girard and John Jacob Astor, were the primary movers. Girard, the largest stockholder in the First Bank at the time of its liquidation, bought up the First Bank's headquarters and its remaining assets in the expectation that the government would soon need a successor bank. ${ }^{115}$ His group then purchased much of the $\$ 16$ million war loan of 1813, and when the government's credit fell, and the price of these bonds fell with it, the group promoted a new national bank as a means to enhance the value of its holdings. ${ }^{116}$ The government's weak financial position, combined with the eagerness of Girard's group to underwrite a new central bank, led to the reconstitution of the Bank of the United States in 1816. Again, monopoly privileges served both the Second Bank's promoters and the government's interests well.

The Second Bank's monopoly powers were superior to those of its predecessor in one important respect: it received de jure recognition as sole depository of the Treasury. For this and its other advantages, the bank paid a "charter fee" to the government of $\$ 1.5$ million. Girard himself took up \$3 million of the Second Bank's capital stock. Yet, the charter of the Second Bank, unlike that of the Bank of England, carried with it no restrictions on the note-issuing powers of banks chartered by the states. This meant that the regulatory turf war between states and the federal government could again pose a threat to the durability of central banking.

Under Nicholas Biddle, the Second Bank parlayed its favored fiscal position into monetary powers, which it employed to make the U.S. dollar "as good [a currency] 
as the best in the world." 117 Biddle employed the Second Bank's monetary powers conservatively, using the exchange rate as a guide for policy. ${ }^{118}$ In addition, the Second Bank acted as a lender of last resort on at least one occasion (1831-32), combining forbearance with an expansion of loans and note issue, and allowing its specie reserve to fall by 41 percent. ${ }^{119}$ These stabilizing activities built widespread support for the central bank in banking circles. Indeed, state bankers were not active opponents of the Second Bank, a fact that undermines Bray Hammond's interest group thesis about the Second Bank's demise. ${ }^{120}$ Not one of the 394 state banks in existence in 1832 petitioned Congress to withdraw the Second Bank's charter, whereas sixtyone sent memorials in favor of renewal. ${ }^{121}$

Many state legislatures had also changed their tune. To explain this recall that until around 1810 state governments typically "sold" bank charters for equity stakes in banks. Under this "equity" regime, states had a fiscal interest in limiting the number of charters they granted. States often demanded large bonus payments for charters, a policy that also required high legal entry barriers, since banks could only recoup these payments in excess profits. By the 1820s, however, states had begun to extract revenue from banks by taxing bank capital, and this new "tax" regime gave states incentives to relax entry in banking. To maximize revenues under a taxation regime, state governments needed to increase the taxable base, which meant increasing the number of banks. ${ }^{122}$

The shift to the taxation regime has direct implications for central bank politics. With state governments less reliant on bank dividends for revenue, yet increasingly dependent on taxing bank capital, the regulatory conflict between states and the national government lessened. No longer concerned about limiting entry in banking, state governments could acquiesce to the Second Bank of the United States. (They did, however, try to tax the Second Bank, but McCulloch v. Maryland put an end to this). Since a state's fiscal interest in bank regulation was no longer at risk by the encroachment of a national bank, states that taxed banks could acknowledge the general advantages of the Second Bank-for example its fiscal support of the national government, its lender-of-last-resort services, and its prudent regulation of the money supply.

As a test of this argument, I expect to find more aggregate support for the Second Bank in Congress than for its predecessor. Furthermore, I expect to find an effect of state regulatory structure on voting patterns, for not all states moved as far or as fast to the taxation regime. Table 5 classifies states by the type of bank regulatory regime they operated in 1832 (tax, equity, mixed) and gives the votes of their state delegations on the House bill to recharter the Second Bank. Note first that by 1832 states were more acceptant in aggregate of central banking than in 1811, since renewal

117. Hammond 1957, 307.

118. See Redlich 1968, 135-37; and Timberlake 1993, 32.

119. Timberlake 1993, 38-39.

120. Hammond 1957.

121. McFaul 1972. See also Wilburn 1964.

122. Wallis, Sylla, and Legler 1994. 
TABLE 5. Bank-derived revenue, state regulatory structure, and the House vote on the Second Bank of the United States, 1832

\begin{tabular}{|c|c|c|c|c|c|}
\hline \multirow[b]{2}{*}{ State } & \multirow{2}{*}{$\begin{array}{l}\text { Bank-derived } \\
\text { revenue (\% of } \\
\text { total revenue })^{\mathrm{a}}\end{array}$} & \multirow{2}{*}{$\begin{array}{l}\text { Second Bank } \\
\text { branches }\end{array}$} & \multirow{2}{*}{$\begin{array}{l}\text { Regulatory regime } \\
\text { (first year) }\end{array}$} & \multicolumn{2}{|c|}{$\begin{array}{l}\text { House vote on the } \\
\text { Second Bank (count) }\end{array}$} \\
\hline & & & & Against & For \\
\hline Mass. & 0.72 & Boston & $\operatorname{tax}(1812)$ & 0 & 12 \\
\hline Conn. & 0.23 & Middletown & $\operatorname{tax}(1814)$ & 0 & 6 \\
\hline Md. & 0.19 & Baltimore & $\operatorname{tax}(1815)$ & 3 & 5 \\
\hline R.I. & 0.14 & Providence & $\operatorname{tax}(1804)$ & 0 & 2 \\
\hline N.J. & 0.13 & & $\operatorname{tax}(1811)$ & 0 & 6 \\
\hline Vt. & 0.08 & Burlington & $\operatorname{tax}(1818)$ & 0 & 3 \\
\hline Ohio & $0.01^{\mathrm{c}}$ & Cincinnati, Chillicothe & $\operatorname{tax}(1815)$ & 3 & 10 \\
\hline Del. & 0.58 & & equity (1794) & 0 & 1 \\
\hline Ga. & 0.28 & Savannah, Augusta & equity (1813) & 6 & 0 \\
\hline S.C. & 0.22 & Charleston & equity (1812) & 6 & 2 \\
\hline Va. & 0.12 & Norfolk, Richmond & equity (1804) & 11 & 6 \\
\hline N.Y. & 0.11 & New York, Buffalo, Utica & equity (1792) & 19 & 12 \\
\hline N.C. & 0.35 & Fayetteville & mixed (1814) & 7 & 4 \\
\hline Pa. & 0.29 & Philadelphia, Pittsburgh & mixed (1817) & 1 & 24 \\
\hline N.H. & 0.19 & Portsmouth & mixed (1821) & 5 & 0 \\
\hline Maine & 0.15 & Portland & mixed (1820) & 6 & 1 \\
\hline Miss. & $0.04^{\mathrm{c}}$ & Natchez & - & 1 & 0 \\
\hline Ill. & $0.03^{\mathrm{c}}$ & & - & - & - \\
\hline Ind. & $0.03^{\mathrm{c}}$ & & - & 2 & 1 \\
\hline Ky. & - & Lexington, Louisville & - & 5 & 6 \\
\hline Tenn. & - & Nashville & - & 7 & 2 \\
\hline La. & - & New Orleans & - & 0 & 3 \\
\hline Ala. & - & Mobile & - & 3 & 0 \\
\hline Mo. & - & St. Louis & - & 0 & 1 \\
\hline Mean & 0.20 & & & 85 & 107 \\
\hline
\end{tabular}

Sources: Sylla, Legler, and Wallis 1987, tab. 1; Wilburn 1964, tab. 1; Wallis, Sylla, and Legler 1994; and Holdsworth 1910, 195.

ancludes bank dividends, taxes, and bonuses paid by banks for charters. Figures are averages for the five-year period 1826-30. A dash indicates insufficient data.

bAn "equity" regime means partial or total state government ownership of banks. A "tax" regime means the state taxes bank capital or profits. A "mixed" regime means the state government both taxes and has equity holdings in banks.

'Decade average, 1825-34.

passed with 57 percent of the vote. Support had increased markedly, even though the states were on average more dependent on bank revenue (column 2), and even though the central bank now had branches in nearly every state (column 3).

A better test is to analyze the effect of regulatory structure on voting patterns, following the procedure used to analyze the 1811 House vote on the First Bank. The expectation is that states taxing banks should show more mean support for the Second Bank than states whose fiscal interest in banks was still primarily in the form of equity stakes. I thus put "yes" votes over the total votes for each state delegation and 
then tested to see whether this proportion was significantly different across the group of states with "equity" regimes (group 1) and the group with "tax" regimes (group 2). The results are shown in Table 6. In the first run I coded "mixed" regimes as equity cases, on the grounds that even some equity participation in banking implies a state interest in limiting bank entry and thus a regulatory conflict with the national government. In the second run I excluded all states with mixed regimes, since, without better data on the share of state revenue derived from taxation versus equity income, it is difficult to accurately specify the intensity of the regulatory conflict. In both runs the results are compelling. Voting does relate to the nature of the regulatory regime, with the proportion of delegations with a tax regime favoring the Second Bank to a much higher degree (0.91) than delegations with an equity regime $(0.38$ including "mixed"; 0.40 excluding "mixed"). The move to the taxation regime in many states-a regime conceived broadly as an alternative to state ownership of bank stock - thus limited the effect of federalism on central bank politics.

Although this interpretation ignores the reasons behind Andrew Jackson's veto of the recharter bill, it does have an internal logic that is often lacking in the literature on the subject. ${ }^{123}$ In a strong federalist system, state authorities compete with the central government as suppliers of bank regulation. They are rival licensers, competing over the authority to extract revenue from banks. Yet the character of the state-level regulatory regime also matters. As shown, when states depended heavily on banks for revenue in the form of equity, they resisted the intrusion of the national government's bank in their territories, for their interest was in restricting the amount of competition with their own bank monopolies. However, with a shift to a taxation regime, the rivalry diminished as states no longer benefited from restricting entry in the banking business.

\section{Conclusion}

Theories of institutions that underscore their collective benefits cannot provide microfoundations for their explanations in terms of individual rational action. ${ }^{124}$ This is the weakness of theories explaining institutions that bound a government to pay its debts, forming the basis of the fiscal-military state. ${ }^{125}$ Central banking is rightly identified as a political institution that arose in response to military threats and the rising costs of war making; on the margin, central banking improved a state's ability to compete in the international system. By consolidating lending to the government, central banking gave creditors the capacity to impose a coordinated credit boycott on governments that behaved opportunistically. This capacity improved state creditworthiness and allowed for a tax-smoothing fiscal strategy-collective benefits that translated into international power. Yet to explain central banking on the basis of the need for

123. See Hammond 1968; Redlich 1968; McFaul 1972; and Wilburn 1964.

124. Knight 1992.

125. See Brewer 1988; and North and Weingast 1989. 
TABLE 6. State regulatory structure and the Second Bank vote

Results including states with "mixed" regimes

\begin{tabular}{|c|c|c|c|c|c|c|}
\hline & & & $n$ & Mean & $S D$ & $S E$ \\
\hline \multicolumn{2}{|c|}{$\begin{array}{l}\text { GROUP } 1 \text { (tax) } \\
\text { GROUP } 2 \text { (equity and mixed) } \\
\text { Mean difference }=0.5310\end{array}$} & & $\begin{array}{l}7 \\
9\end{array}$ & $\begin{array}{l}0.9143 \\
0.3833\end{array}$ & $\begin{array}{l}0.152 \\
0.368\end{array}$ & $\begin{array}{l}0.057 \\
0.123\end{array}$ \\
\hline Variances & $t$-value & $D F$ & & 2-tailed sig. & SE of diff. & $95 \%$ CI for diff. \\
\hline Equal & 3.56 & 14 & & .003 & 0.149 & $(0.211,0.851)$ \\
\hline Unequal & 3.92 & 11.17 & & .002 & 0.136 & $(0.233,0.829)$ \\
\hline
\end{tabular}

Note: Data are from Table 5. $X_{1}$ : Regulatory regime $\left(1=\operatorname{tax}, 2=\right.$ equity and mixed). $Y_{1}$ : Percentage of vote for renewal (yes vote divided by total state delegation vote).

Results excluding states with "mixed" regimes

\begin{tabular}{|c|c|c|c|c|c|}
\hline & & $n$ & Mean & $S D$ & $S E$ \\
\hline \multicolumn{2}{|c|}{$\begin{array}{l}\text { GROUP } 1 \text { (tax) } \\
\text { GROUP } 2 \text { (equity) } \\
\text { Mean difference }=-0.5163 .\end{array}$} & $\begin{array}{l}7 \\
5\end{array}$ & $\begin{array}{l}0.9143 \\
0.3980\end{array}$ & $\begin{array}{l}0.152 \\
0.369\end{array}$ & $\begin{array}{l}0.057 \\
0.165\end{array}$ \\
\hline Variances & $t$-value & $D F$ & 2-tailed sig. & SE of diff. & $95 \%$ CI for diff. \\
\hline $\begin{array}{l}\text { Equal } \\
\text { Unequal }\end{array}$ & $\begin{array}{l}3.37 \\
2.95\end{array}$ & $\begin{array}{l}10 \\
4.98\end{array}$ & $\begin{array}{l}.007 \\
.032\end{array}$ & $\begin{array}{l}0.153 \\
0.175\end{array}$ & $\begin{array}{r}(0.175,0.857) \\
(0.066,0.966)\end{array}$ \\
\hline
\end{tabular}

Note: Data are from Table 5. $X_{1}$ : Regulatory regime $\left(1=\operatorname{tax}, 2=\right.$ equity). $Y_{1}$ : Percentage of vote for renewal (yes vote divided by total state delegation vote).

these benefits does not resolve problems of collective action and free riding. Indeed, the public character of the benefits implies great difficulty in forming the institution.

The joint-products model resolves the puzzle. The charters of early central banks contained both public and private goods, precisely because these goods would have been difficult to produce separately. On the one hand, governments facing military challenges needed to borrow, and sought a special bank that would lend its capital to 
the government, and thereby smooth the costs of high current expenditures over time. These were public goods from the standpoint of society. On the other hand, a narrow subgroup wanted government-sanctioned rents-a private good-which the government was in a unique position to provide. This formed the basis of an exchange in which the public benefits were partially internalized by rent seekers. In the exchange, the subgroup obtained monopoly rights in banking and government finances for large payments to the government. The granting of special privileges to a single bank was the selective incentive that facilitated the production of an institution that helped the government finance wartime expenditures with a policy of tax smoothing.

The most important implication of this analysis is that society can benefit from the rent-seeking activities of a narrow segment of the population. ${ }^{126}$ This claim is counterintuitive, since the core insight of the rent-seeking literature is that the activity is inherently wasteful; a form of "directly unproductive" behavior. ${ }^{127}$ Nevertheless, when one or more actors create an institution with public purposes in order to extract private benefits from society, the behavior is productive. Social welfare is advanced when the institution yields net welfare gains larger than the deadweight costs of the legal market restrictions. In the case of monopoly central banking, the distortions in the banking market could hardly have been greater than the general benefits derived from enhanced public creditworthiness, especially in the context of military conflict.

Since the argument runs headlong into the idea that rent seeking is inherently bad for society, it is not surprising that it generates paradoxical findings. For example, a more effective central banking monopoly may actually improve the prospects for public goods provision. Contrast the Bank of England with the Bank of the United States in this respect. The former's monopoly was nearly complete for over a century, due to England's centralized regulatory system, and the only banks that arose were small and restricted. The consequence was that political opposition was contained, and the Bank of England was able to sustain its dominance as banker to the government and, ultimately, in money creation. The government's credit was never stronger and this, in turn, aided Britain's rise in the international system. In contrast, federalism in the United States meant that the national government faced fierce competition from the states in chartering banks, and this weakened the central bank in national politics. ${ }^{128}$ Liquidating the First Bank was costly to the nation. Without a central bank to support it, the government's credit fell, and the Treasury was forced to resort to inflation to finance the War of 1812. The cycle of inflation, the breakdown of the specie standard, and then deflation and resumption might have been avoided had the First Bank survived. To the extent that the gains derived from public creditworthiness exceeded the sum of the deadweight costs associated with the monopoly distortions, the central bank exchange was welfare improving.

126. For a related analysis, see Gradstein 1993.

127. Bhagwati 1982.

128. For a joint-products analysis of the Federal Reserve Act, see Broz 1997. 
Beyond central banking, the joint-products framework is relevant to a range of important welfare-improving foreign policy institutions. For example, freer trade policies are rooted in the institution of reciprocity, wherein trade liberalization occurs on a quid pro quo basis between nations. ${ }^{129}$ Reciprocity promotes freer trade (a public good), because it privatizes the benefits of liberalization on the export interests that receive the sector-specific foreign trade concessions. ${ }^{130}$ In the absence of reciprocity, the costs of liberalization are concentrated on specific industries, whereas the benefits accrue to the community at large, making liberalization difficult. Reciprocity solves a domestic collective action problem by enabling a subset of societyexporters-to lobby for liberalization. ${ }^{131}$

The regulation of globally integrated financial systems is another area where the joint-products model can serve as a useful guide to emerging institutions. The globalization of financial markets has lead to the realization that the safety and soundness of domestic financial systems require international cooperation, since serious shocks can arise from outside national borders (for example, the debt crisis). Hence, states have moved to coordinate their regulatory standards, most notably with the Basle Accord of 1987, which established a risk-weighed capital-adequacy standard for G-10 nations. Yet the goal of the accord was not confined to providing the public good of a more stable international financial environment. In fact, for the states that lobbied hardest for the accord, a key objective was to level the regulatory playing field vis-à-vis Japan - a private good with respect to the banks operating under tougher capital adequacy rules in the United States and England. ${ }^{132}$ Indeed, joint products are implicit in the view that "once countries agree to address a potential spillover, such as systemic risk, they may be impelled by domestic political forces to accomplish the objective in a way that attempts to level the playing field." 133

Students of international alliances and international environmental agreements have also shown how joint production facilitates providing these public goods. In addition to the collective good of deterring common enemies, alliancewide expenditures yield many benefits that are private between allies. For example, alliance armaments can be used to maintain domestic order, generate foreign exchange, and develop a host nation's arms industry and other infrastructure (headquarters, airfields, training facilities, and so on). Empirical analyses establish a strong relationship between individual ally defense efforts and the incidence of private benefits. ${ }^{134}$ Similarly, Todd Sandler models the global environmental problem of tropical deforestation in jointproduct terms. ${ }^{135}$ Protection of rain forests provides global public goods (carbon sequestration and tropical biodiversity) as well as local benefits to the host countries (watersheds, erosion control, localized climate benefits, and nutrient recycling). Hence,

129. Tumlir 1985.

130. Bailey, Goldstein, and Weingast 1997; Roessler 1978.

131. Gilligan, forthcoming.

132. Kapstein 1991.

133. Herring and Litan 1995, 109.

134. See Murdoch and Sandler 1982; and Conybeare and Sandler 1990.

135. Sandler 1993. 
tropical countries have vested interests to do more to protect their forests. In turn the positive externalities conferred on developed nations, in terms of carbon storage and gene pools, impels these nations to assist in the preservation effort, as in the Rio Earth Summit of 1992.

Inasmuch as institutions exist to solve collective action problems that impede the attainment of social objectives, their origins are subject to the same dilemmas they are meant to resolve. The puzzle lies in explaining how large groups of rational, but socially disconnected individuals (or nation-states) arrive at cooperative outcomes and produce the institutional public goods that govern their behavior. My point is that institutions provide excludable goods jointly with public goods, making distributional considerations essential to understanding institutional innovation. It is this concentrated distribution that gives individuals incentives to build institutions, like central banks, that benefit the whole community.

\section{References}

Andreades, A. 1924. History of the Bank of England. London: P. S. King. Angell, Norman. 1929. The Story of Money. New York: Frederick A. Stokes.

Ashton, T. S. 1959. Economic Fluctuations in England. Oxford: Oxford University Press.

Bagehot, Walter. [1873] 1979. Lombard Street. Reprint, Westport, Conn.: Hyperion Press.

Bailey, Michael, Judith Goldstein, and Barry Weingast. 1997. The Institutional Roots of American Trade Policy. World Politics 49:309-38.

Barro, Robert J. 1987. Macroeconomics. 2d ed. New York: John Wiley and Sons.

Bates, Robert. 1988. Contra-Contractarianism. Politics and Society 16:394-95.

Becker, Gary S. 1985. Public Policies, Pressure Groups, and Dead Weight Costs. Journal of Public Economics 28:329-47.

Beckett, J. V. 1986. The Aristocracy in England, 1660-1914. Oxford: Basil Blackwell.

Bhagwati, Jagdish. 1982. Directly-Unproductive, Profit-Seeking (DUP) Activities. Journal of Political Economy 90:988-1002.

Bowen, H. V. 1995. The Bank of England During the Long Eighteenth Century, 1694-1820. In The Bank of England, edited by Richard Roberts and David Kynaston, 1-19. Oxford: Oxford University Press.

Brewer, John. 1988. The Sinews of Power: War, Money, and the English State. New York: Knopf.

Brown, Kenneth L. 1942. Stephen Girard, Promoter of the Second Bank of the United States. Journal of Economic History 2:145-52.

Broz, J. Lawrence. 1997. The International Origins of the Federal Reserve System. Ithaca, N.Y.: Cornell University Press.

Cain, P. J., and A. G. Hopkins. 1986. Gentlemanly Capitalism and British Expansionism Overseas, 16881850. Economic History Review 39: 501-25.

Carruthers, Bruce G. 1996. City of Capital: Politics and Markets in the English Financial Revolution. Princeton, N.J.: Princeton University Press.

Clapham, John H. 1944. The Bank of England: A History. Cambridge: Cambridge University Press.

Clarke, Matthew, and David A. Hall. 1832. Legislative and Documentary History of the Bank of the United States. Washington, D.C.: Gales and Seaton.

Conant, Charles A. 1915. A History of Modern Banks of Issue. New York: G. P. Putnam's Sons.

Conybeare, John A. C. and Todd Sandler. 1990. The Triple Entente and the Triple Alliance, 1889-1914: A Collective Goods Approach. American Political Science Review 84:1197-1205.

Cornes, Richard, and Todd Sandler. 1986. The Theory of Externalities, Public Goods, and Clubs. Cambridge: Cambridge University Press. 
de Vries, Johan. 1994. The Netherlands's Financial Empire. In Handbook on the History of European Banks, edited by Manfred Pohl, 719-30. Aldershot: Edward Elgar.

Dickson, P. G. M. 1967. The Financial Revolution in England. London: Macmillan, 1967.

Dickson, P. G. M., and J. G. Sperling. 1970. War Finance, 1689-1714. In The New Cambridge Modern History: The Rise of Great Britain and Russia, 1688-1725. Vol. 6, edited by J. S. Bromley. Cambridge: Cambridge University Press.

Feavearyear, Albert. 1963. The Pound Sterling. Oxford: Clarendon Press.

Fenstermaker, J. Van. 1965. The Development of American Commercial Banking, 1787-1837. Kent, Ohio: Kent State University Press.

Fetter, Frank W. 1965. Development of British Monetary Orthodoxy, 1797-1875. Cambridge: Cambridge University Press.

Frieden, Jeffry. 1991. Invested Interests: The Politics of National Economic Policies in a World of Global Finance. International Organization 45:425-51.

Furgeson, James E. 1961. The Power of the Purse: A History of American Public Finance, 1776-1790. Chapel Hill: University of North Carolina Press.

Galbraith, John K. 1975. Money: Whence It Came, Where It Went. Boston: Houghton Mifflin.

Gilligan, Michael. Forthcoming. Empowering Exporters: Reciprocity and Collective Action in Twentieth Century American Trade Policy. Ann Arbor: University of Michigan Press.

Goodhart, Charles A. E. 1988. The Evolution of Central Banks. Cambridge, Mass.: MIT Press. 1995. What Do Central Banks Do? In The Central Bank and the Financial System, edited by Charles Goodhart. Cambridge, Mass.: MIT Press.

Goodhart, Charles, Forrest Capie, and Norbert Schnadt. 1994. The Development of Central Banking. In The Future of Central Banking, edited by Forrest Capie, Charles Goodhart, Stanley Fischer, and Norbert Schnadt. Cambridge: Cambridge University Press.

Grief, Avner, Paul Milgrom, and Barry R. Weingast. 1994. Coordination, Commitment, and Enforcement: The Case of the Merchant Guild. Journal of Political Economy 102:745-76.

Hamilton, E. J. 1945. The Foundation of the Bank of Spain. Journal of Political Economy 53:97-114.

Hammond, Bray. 1957. Banks and Politics in America. Princeton, N.J.: Princeton University Press.

Hardin, Russell. 1982. Collective Action. Baltimore, Md.: The Johns Hopkins University Press.

Herring, Richard J., and Robert Litan. 1995. Financial Regulation in the Global Economy. Washington,

D.C.: Brookings Institution.

Hicks, John R. 1969. A Theory of Economic History. Oxford: Oxford University Press.

Hilton, Boyd. 1977. Corn, Cash, Commerce: Economic Policies of the Tory Governments 1815-1830. London: Oxford University Press.

Holdsworth, John T. 1910. The First Bank of the United States. Washington, D.C.: U.S. Government Printing Office.

Horsefield, Keith J. 1960. British Monetary Experiments, 1650-1710. Cambridge, Mass.: Harvard University Press.

Jenks, Leland. 1924. The Migration of British Capital to 1875. New York: Knopf.

Johnson, Brian. 1970. The Politics of Money. London: John Murray.

Jones, J. R. 1994. Fiscal Policies, Liberties, and Representative Government During the Reigns of the Last

Stuarts. In Fiscal Crises, Liberty, and Representative Government, edited by Philip T. Hoffman and Kathryn Norberg, 67-95. Stanford, Calif.: Stanford University Press.

Kapstein, Ethan B. 1991. Supervising International Banks: Origins and Implications of the Basle Accord. Essays in International Finance, 185. Princeton, N.J.: Department of Economics, Princeton University.

Keynes, John M. 1924. Monetary Reform. New York: Harcourt, Brace.

Knight, Jack. 1992. Institutions and Social Conflict. Cambridge: Cambridge University Press.

Lake, David A. 1992. Powerful Pacifists: Democratic States and War. American Political Science Review 86:24-38.

Landmann, J. 1911. The Swiss Banking Law. In Banking in Sweden and Switzerland, edited by J. Landmann. Washington D.C.: U.S. Government Printing Office.

Lodge, Henry C., ed. 1904. The Works of Alexander Hamilton. New York: G. P. Putnam's Sons.

Macaulay, Thomas B. 1831. The History of England from the Accession of James II. Boston: DeWolfe. 
Macleod, Henry D. 1923. The Theory and Practice of Banking. London: Longmans, Green and Co.

McFaul, John M. 1972. The Politics of Jacksonian Finance. Ithaca, N.Y.: Cornell University Press.

Mishan, Ezra J. 1969. The Relationship Between Joint Products, Collective Goods, and External Effects. Journal of Political Economy 77:329-48.

Morgan, H. Wayne. 1956. The Origins and Establishment of the First Bank of the United States. Business History Review 30:472-92.

Morgan, Victor E. 1943. The Theory and Practice of Central Banking, 1797-1913. London: Cambridge University Press.

Murdoch, J., and T. Sandler. 1982. A Theoretical and Empirical Analysis of NATO. Journal of Conflict Resolution 24:237-63.

North, Douglass C. 1981. Structure and Change in Economic History. New York: W. W. Norton.

North, Douglass C., and Barry R. Weingast. 1989. Constitutions and Commitment: The Evolution of Institutions Governing Public Choice in Seventeenth-Centur y England. Journal of Economic History 49:803-32.

Olson, Mancur. 1965. The Logic of Collective Action. Cambridge, Mass.: Harvard University Press.

Olsson, Ulf. 1994. Swedish Commercial Banking over 150 Years. In Handbook on the History of European Banks, edited by Manfred Pohl, 963-75. Aldershot: Edward Elgar.

Pohl, Manfred, ed. 1994. Handbook on the History of European Banks. Aldershot: Edward Elgar.

Posnett, John, and Todd Sandler. 1986. Joint Supply and the Finance of Charitable Activity. Public Finance Quarterly 14:209-22.

Powell, Ellis T. 1966. The Evolution of the Money Market. New York: Augustus M. Kelly.

Redlich, Fritz. 1968. The Molding of American Banking. New York: Johnson Reprint Company.

Ricardo, David. [1816] 1951. The Works and Correspondence of David Ricardo. Reprint, Cambridge: Cambridge University Press.

Rogers, Thorold. 1887. The First Nine Years of the Bank of England. London: P. S. King.

Root, Hilton L. 1994. The Fountain of Privilege: Political Foundations of Markets in Old Regime France and England. Berkeley: University of California Press.

Roessler, F. 1978. The Rationale for Reciprocity in Trade Negotiations. Kyklos 31:258-74.

Rowe, J. Z. 1965. The Public-Private Character of United States Central Banking. New Brunswick, N.J.: Rutgers University Press.

Russell, Steven. 1991. The U.S. Currency System in Historical Perspective. Federal Reserve Bank of St. Louis Review 73:34-61.

Sandler, Todd. 1992. Collective Action. Ann Arbor: University of Michigan Press.

1993. Tropical Deforestation: Markets and Market Failures. Land Economics 69: 225-33.

Santoni, G. J. 1984. A Private Central Bank: Some Olde English Lessons. Federal Reserve Bank of St. Louis Review 66:2-22.

Sargent, Thomas, and Francois Velde. 1995. Macroeconomic Features of the French Revolution. Journal of Political Economy 103:474-518.

Schultz, Kenneth A., and Barry R. Weingast. 1996. The Democratic Advantage: The Institutional Sources of State Power in International Competition. Essays in Public Policy, 67. Stanford, Calif.: Hoover Institution on War, Revolution, and Peace, Stanford University.

Smith, Vera C. [1936] 1990. The Rationale for Central Banking. Reprint, Indianapolis, Ind.: Liberty Press.

Stigler, George J. 1974. Free Riders and Collective Action: An Appendix to Theories of Economic Regulation. Bell Journal of Economics and Management Science 5:359-65.

Sylla, Richard, John B. Legler, and John J. Wallis. 1987. Banks and State Public Finance in the New Republic: The United States, 1790-1860. Journal of Economic History 47:391-403.

Timberlake, Richard H., Jr. 1993. Monetary Policy in the United States: An Intellectual and Institutional History. Chicago: University of Chicago Press.

Tracy, Michael. 1989. Government and Agriculture in Western Europe. New York: Harvester Wheatsheaf. Tumlir, Jan. 1985. Protectionism. Washington, D.C.: American Enterprise Institute.

Wallis, John W., Richard E. Sylla, and John B. Legler. 1994. The Interaction of Taxation and Regulation in Nineteenth-Century U.S. Banking. In The Regulated Economy, edited by Claudia Goldin and Gary Liebcap, 121-44. Chicago: National Bureau of Economic Research. 
Weingast, Barry R. 1992. Institutional Foundations of the "Sinews of Power": British Financial and Military Success Following the Glorious Revolution. Hoover Institution on War, Revolution, and Peace, Stanford University, Stanford, Calif. Mimeo.

Wettereau, James O. 1937. New Light on the First Bank of the United States. Pennsylvania Magazine of History and Biography 61:263-85.

White, Lawrence H. 1984. Free Banking in Britain. Cambridge: Cambridge University Press. 1989. Competition and Currency. New York: New York University Press.

Wilburn, Jean A. 1964. Biddle's Bank. New York: Columbia University Press.

Williamson, Oliver E. 1985. The Economic Institutions of Capitalism. New York: Free Press.

Wilson, John S. 1957. French Banking Structure and Credit Policy. Cambridge, Mass.: Harvard University Press. 